\title{
Minha Amiga Marta
}

Yone Soares de Lima ${ }^{1}$

Tive um sonho. Nele, Marta viajara para longe, muito longe. Partiu tranqüila, certa de que encontraria velhos conhecidos, personagens familiarizados com nossas pesquisas. Iria "descobrir coisas" a respeito deles e das atividades artísticas de quando por aqui passaram. Provavelmente traria novas informações que, em seu retorno, esclareceriam as muitas dúvidas, ainda sem respostas...

Mas o despertar de um sonho quase sempre nos revela uma realidade cruel, colocando-nos em choque com a verdade. Confesso, levei algum tempo para recuperar-me.

Lembro-me bem de como nos conhecemos. Foi após o concurso que eu havia prestado para exercer a pesquisa de Arte Brasileira no Instituto de Estudos Brasileiros da Universidade de São Paulo, então sob a direção do Professor José Aderaldo Castello. Ele próprio me acompanhou à Coleção Mário de Andrade, fazendo questão de mostrar a mesa de trabalho e com quem iria dividir aquele "espaço sagrado": aquela que iria ser a colega, companheira e amiga para sempre. Marta veio receber-me com um sorriso de lábios cerrados para logo se abrir num outro, largo e acolhedor, que cedo aprendi a conhecer como uma de suas características. Vestia um guarda-pó branco, aquele adotado pelos pesquisadores do Instituto, que deixava ver o elegante talhe de calça comprida, peça de vestuário que jamais abriu mão de usar. Com seu inseparável cigarrinho (na época era permitido), logo me colocou a par do que era a Coleção e sua importância cultural para a História das Artes no Brasil.

Nascia ali nossa amizade. Uma amizade que vimos crescer e fortalecer-se com o passar do tempo. Não só pelo envolvimento no trabalho em si, mas pela afinidade que nos foi aproximando, fraternal e espiritualmente, para além da esfera universitária.

Se eu era perfeccionista, Marta o era ainda mais, minuciosa e exigente consigo mesma. Incansável em tudo que empreendia fazer, seu jeito de ser muito contribuiu para a harmonização de nossas pesquisas. Dificilmente divergíamos sobre algum ponto de vista, ao contrário, havia uma constante troca de informação através de inesquecíveis "bate-papos”.

1 Docente do IEB (área de Artes Plásticas). 
Visitas a museus e colecionadores, contatos com especialistas em arte, entrevistas, cursos e viagens, que fizemos juntas ou individualmente, serviram para enriquecer nossos apontamentos e trabalhos em andamento e futuros.

Em razão do grande número de peças e objetos da Coleção, criamos inicialmente uma espécie de "linha divisória" no acervo, com o propósito de dinamizar e racionalizar nosso trabalho, optando, assim, por definir quais obras e autores ficariam sob a responsabilidade de cada uma. Levamos em conta o histórico das peças no acervo e, respeitando as preferências pessoais, fizemos nossas escolhas reunindo, ao final, os estudos para a organização do Catálogo da Coleção, objetivo primordial do Setor.

De imediato, Marta elegeu para si Anita Malfatti: estudou a fundo e elucidou a formação artística e a personalidade da pintora. Havia, acredito, uma grande empatia entre ambas. Além de ter usufruído do convívio por bom tempo, Marta foi sempre bem recebida pela família de Anita. Foram anos de muita dedicação e amizade aos quais testemunhei de perto.

Corriam os anos setenta e formávamos um grupo de onze pesquisadores de Estudos Brasileiros, inicialmente denominados de historiógrafos. A área de Literatura era responsabilidade de Yêdda Dias Lima, Telê Ancona Lopez, Cecília de Lara e Camila Mendes Ruiz. Pela área da História respondiam Arlinda Rocha Nogueira, Lucy Maffei Hutter, Heloísa Liberalli Belloto e José Eduardo Marques Mauro. Pela área de Antropologia, Ruth Terra, enquanto Marta Rossetti Baptista e eu éramos responsáveis pela Coleção Mário de Andrade. Anos mais tarde, o grupo seria ampliado pelo setor de Música, com Flávia Toni. A Biblioteca com suas coleções de livros raros e primeiras edições ficava sob a guarda de Rosemarie E. Horch, Catarina Cristóforo e Maria Itália Causin. Na época, o Arquivo engatinhava em sua organização, mas, mesmo assim, era procurado com interesse por pesquisadores e consulentes. 0 Instituto não dispunha de grande espaço físico, no entanto, já possuía invejável acervo cultural. Contava com um pequeno grupo de auxiliares, como o motorista, Sr. Bravo e Dna. Brasilina, que na copa fazia como ninguém o cafezinho que ela mesma levava de sala em sala. Ivone Chamelet, olhos lindos, secretariava o Diretor e o Instituto. Foi um tempo em que todos se conheciam e se comunicavam com maior facilidade, talvez pela proximidade das salas que ocupávamos, dando a sensação de aconchego. Lembro bem da Marta com suas idas e vindas à Biblioteca e ao Arquivo, com seu passinho miúdo e rápido. Uma época que deixou saudade.

Periodicamente o Diretor, Professor Castello, nos convocava para reuniões em sua sala. Era a oportunidade para cada 
área se pronunciar, apresentando relatórios, planos, realizações individuais ou de equipe e, por vezes, trabalhos já iniciados.

Em uma dessas reuniões, surgiram as primeiras idéias para aquele que seria um dos mais significativos eventos do IEB - "a menina dos olhos" de Marta: grandes composições fotográficas distribuídas por dez painéis em que o acervo do Instituto estava amplamente representado - a coleção de Artes, o Arquivo e a Biblioteca. Um trabalho de grupo que exigiu muito de muitos, inclusive de Marta, grávida do Humberto na época. Foi uma realização trabalhosa que frutificou na publicação Brasil: $1^{0}$ Tempo Modernista - 1917/1929 - Documentação, 1972, palestras, cursos, debates, etc., e uma versão de Mostra itinerante. Marta, sempre presente, supervisionava tudo sem, no entanto, abandonar "sua Anita".

Com os anos oitenta chegando, o IEB transferiu-se para um dos prédios do CRUSP: mudaram as instalações, com isso a sala da Direção, a Biblioteca, o Arquivo e a Coleção. Mas não mudamos nós. Nossas pesquisas, projetos e os cuidados com o Acervo continuaram. Disso não abrimos mão. Marta como arquiteta acompanhou algumas adaptações no prédio, sugerindo que se instalasse meia parede com vidro entre nós e a sala de exposição, agora com funcionário para acompanhar os visitantes. Havia mais espaço para expor as obras, objetos, imagens religiosas, inclusive para os móveis doados pela família de Mário de Andrade.

Essa nova situação deu-nos condições de ampliar também alguns planos para o Setor de Artes. Exposições periódicas, com destaque para alguns artistas, obras ou conjunto de peças de outros setores: livros raros da Biblioteca ou documentos inéditos guardados no Arquivo, já organizado e sob a responsabilidade de Maria Izilda, Cecilinha e Maria Helena.

O Instituto contava na época com numeroso corpo de funcionários e na sucessão de diretores Marta assume, indicada pelo Conselho e apoiada por toda a equipe de trabalho. Benquista por todos e bem relacionada, Marta certamente deixou seu nome na Universidade de São Paulo e nos meios culturais, através de sua memorável produção intelectual. Algumas de suas mais belas obras foram editadas quando eu já retornara ao Sul. Nossa amizade jamais diminuiu apesar da distância muitas vezes lamentada em conversas telefônicas.

Ainda dói em meus ouvidos a voz solene de Luís Olavo “... acabou, Yone...” 